\title{
27. ELASTIC WAVE VELOCITIES IN VOLCANIC AND PLUTONIC ROCKS RECOVERED ON DSDP LEG 31
}

\author{
N.I. Christensen, R.L. Carlson, M.H. Salisbury, and D.M. Fountain, \\ Department of Geological Sciences, University of Washington, Seattle, Washington
}

\section{INTRODUCTION}

In this paper information is presented on compressional and shear wave velocities, bulk densities, and elastic constants for several samples of basement rock obtained from Sites 292, 293, 294, and 296. The velocities have been measured to 4.0 or $6.0 \mathrm{~kb}$ using a pulse transmission technique similar to that described by Birch (1960).

The rocks studied from Site 292 are fine-grained basalts with intersertal to subophitic textures; all samples are vesicular and slightly altered. The rocks from Site 293 are of particular significance in that they may represent samples from the lower oceanic crust. Compressional wave velocities were measured in metadiabase containing abundant actinolite after clinopyroxene (31-293-18-1, 90-93 cm); granulatedchloritized gabbro (31-293-19-1, 108-111 cm); hornblende metagabbro of amphibolite facies grade (293-20-1, 100-103 cm); and gabbro tending towards anorthositic gabbro, often with cumulate textures and strong preferred orientation of plagioclase (31-293-20-1, $136-139 \mathrm{~cm} ; 31-293-21-1,5-8 \mathrm{~cm} ; 31-293-21-1,32-35 \mathrm{~cm}$; and $31-293-21-2,11-14 \mathrm{~cm}$ ). The sample from Site 294 is a fine-grained, altered basalt with an intersertal texture, whereas the sample from Site 296 is a lapilli tuff.

\section{DATA}

The velocities and bulk densities of the samples are given in Table 1. The samples were stored in water immediately after their recovery. Since it has been shown that at pressures below a few kilobars, water saturation significantly increases compressional wave velocities (e.g., Wyllie et al., 1958; Nur and Simmons, 1969; Christensen, 1970), the velocities were measured under saturated conditions. Pore pressures were maintained at values lower than external pressures by placing 100mesh screen between the samples and copper jackets.

Ratios of compressional to shear velocities $\left(V_{p} / V_{s}\right)$, Poisson's ratios $(\sigma)$, seismic parameters $(\phi)$, bulk moduli

TABLE 1

Compressional (P) and Shear (S) Wave Velocities

\begin{tabular}{|c|c|c|c|c|c|c|c|c|c|c|}
\hline \multirow[b]{2}{*}{$\begin{array}{c}\text { Sample } \\
\text { (Interval in } \mathrm{cm} \text { ) }\end{array}$} & \multirow[b]{2}{*}{$\begin{array}{c}\text { Bulk } \\
\text { Density }\end{array}$} & \multirow[b]{2}{*}{ Mode } & \multicolumn{8}{|c|}{ Velocity $(\mathrm{km} / \mathrm{sec})$ at Varying Pressures } \\
\hline & & & $0.2 \mathrm{~kb}$ & $0.4 \mathrm{~kb}$ & $0.6 \mathrm{~kb}$ & $0.8 \mathrm{~kb}$ & $1.0 \mathrm{~kb}$ & $2.0 \mathrm{~kb}$ & $4.0 \mathrm{~kb}$ & $6.0 \mathrm{~kb}$ \\
\hline $292-41-2,37-40$ & $\begin{array}{l}2.567 \\
2.567\end{array}$ & $\begin{array}{l}\mathrm{P} \\
\mathrm{S}\end{array}$ & $\begin{array}{l}4.63 \\
2.41\end{array}$ & $\begin{array}{l}4.71 \\
2.45\end{array}$ & $\begin{array}{l}4.78 \\
2.48\end{array}$ & $\begin{array}{l}4.84 \\
2.50\end{array}$ & $\begin{array}{l}4.89 \\
2.53\end{array}$ & $\begin{array}{l}5.06 \\
2.62\end{array}$ & $\begin{array}{l}5.28 \\
2.69\end{array}$ & - \\
\hline $292-41-5,40-43$ & $\begin{array}{l}2.611 \\
2.611\end{array}$ & $\begin{array}{l}\mathrm{P} \\
\mathrm{S}\end{array}$ & $\begin{array}{l}4.88 \\
2.48\end{array}$ & $\begin{array}{l}4.93 \\
2.52\end{array}$ & $\begin{array}{l}4.97 \\
2.56\end{array}$ & $\begin{array}{l}5.01 \\
2.59\end{array}$ & $\begin{array}{l}5.04 \\
2.62\end{array}$ & $\begin{array}{l}5.21 \\
2.71\end{array}$ & $\begin{array}{l}5.39 \\
2.80\end{array}$ & - \\
\hline $292-42-5,29-32$ & $\begin{array}{l}2.607 \\
2.607\end{array}$ & $\begin{array}{l}\mathrm{P} \\
\mathrm{S}\end{array}$ & $\begin{array}{l}5.04 \\
2.64\end{array}$ & $\begin{array}{l}5.09 \\
2.66\end{array}$ & $\begin{array}{l}5.13 \\
2.68\end{array}$ & $\begin{array}{l}5.16 \\
2.70\end{array}$ & $\begin{array}{l}5.19 \\
2.72\end{array}$ & $\begin{array}{l}5.29 \\
2.77\end{array}$ & $\begin{array}{l}5.41 \\
2.83\end{array}$ & - \\
\hline $292-43-4,40-43$ & $\begin{array}{l}2.675 \\
2.675\end{array}$ & $\begin{array}{l}\mathrm{P} \\
\mathrm{S}\end{array}$ & $\begin{array}{l}4.98 \\
2.66\end{array}$ & $\begin{array}{l}5.04 \\
2.69\end{array}$ & $\begin{array}{l}5.09 \\
2.71\end{array}$ & $\begin{array}{l}5.13 \\
2.73\end{array}$ & $\begin{array}{l}5.16 \\
2.74\end{array}$ & $\begin{array}{l}5.26 \\
2.79\end{array}$ & $\begin{array}{l}5.36 \\
2.84\end{array}$ & - \\
\hline $292-44-4,48-51$ & $\begin{array}{l}2.688 \\
2.688\end{array}$ & $\begin{array}{l}\mathrm{P} \\
\mathrm{S}\end{array}$ & $\begin{array}{l}5.09 \\
2.73\end{array}$ & $\begin{array}{l}5.16 \\
2.75\end{array}$ & $\begin{array}{l}5.21 \\
2.77\end{array}$ & $\begin{array}{l}5.24 \\
2.78\end{array}$ & $\begin{array}{l}5.27 \\
2.79\end{array}$ & $\begin{array}{l}5.34 \\
2.84\end{array}$ & $\begin{array}{l}5.45 \\
2.89\end{array}$ & - \\
\hline $292-46, \mathrm{CC}$ & 2.792 & $\mathrm{P}$ & 5.33 & 5.39 & 5.43 & 5.47 & 5.50 & 5.61 & 5.73 & - \\
\hline $293-18-1,90-93$ & 2.828 & $\mathbf{P}$ & 6.21 & 6.23 & 6.25 & 6.26 & 6.27 & 6.33 & 6.44 & 6.53 \\
\hline $293-19-1,108-111$ & 2.848 & $P$ & 6.51 & 6.53 & 6.55 & 6.57 & 6.58 & 6.63 & 6.70 & 6.74 \\
\hline $293-20-1,100-103$ & 2.853 & $\mathbf{P}$ & 6.49 & 6.56 & 6.62 & 6.67 & 6.71 & 6.80 & 6.86 & - \\
\hline $293-20-1,136-139$ & 2.832 & $\mathrm{P}$ & 6.80 & 6.85 & 6.89 & 6.93 & 6.95 & 7.02 & 7.10 & 7.16 \\
\hline $293-21-1,5-8$ & 2.939 & $P$ & 6.80 & 6.83 & 6.85 & 6.87 & 6.88 & 6.95 & 7.05 & 7.10 \\
\hline $293-21-1,32-35$ & 2.938 & $\mathbf{P}$ & 6.77 & 6.82 & 6.85 & 6.88 & 6.91 & 7.00 & 7.07 & - \\
\hline $293-21-2,11-14$ & 2.933 & $\mathrm{P}$ & 6.99 & 7.01 & 7.03 & 7.05 & 7.06 & 7.11 & 7.17 & 7.23 \\
\hline $294-7-1,116-119$ & $\begin{array}{l}2.462 \\
2.462\end{array}$ & $\begin{array}{l}\mathrm{P} \\
\mathrm{S}\end{array}$ & $\begin{array}{l}4.63 \\
2.30\end{array}$ & $\begin{array}{l}4.69 \\
2.35\end{array}$ & $\begin{array}{l}4.73 \\
2.38\end{array}$ & $\begin{array}{l}4.75 \\
2.42\end{array}$ & $\begin{array}{l}4.78 \\
2.45\end{array}$ & $\begin{array}{l}4.88 \\
2.55\end{array}$ & $\begin{array}{l}5.04 \\
2.66\end{array}$ & $\begin{array}{c}5.14 \\
-\end{array}$ \\
\hline $296-56-6,10-13$ & 1.985 & $\mathbf{P}$ & 3.93 & 3.95 & 3.96 & 3.97 & 3.98 & 4.00 & 4.02 & - \\
\hline
\end{tabular}


$(K)$, compressibilities $(\beta)$, shear moduli $(\mu)$, Young's moduli $(E)$, and Lamé's constant $(\lambda)$ calculated from densities and velocities are given for selected pressures in Table 2. Shear velocities and elastic constants are not reported for the samples from Site 293 because of probable anisotropy of these rocks resulting from strong preferred mineral orientation.

\section{VELOCITY-DENSITY RELATIONS}

In a previous report, Christensen et al. (1974) suggested that velocity-density relations for DSDP basalts might be more appropriately described by a nonlinear curve than by the linear solutions commonly used. Figure 1 shows a plot of velocity versus density for water-saturated DSDP basalts at $0.5 \mathrm{~kb}$ from this study, and from previous work (Christensen and Salisbury, 1972, 1973; Christensen et al., 1974). The data have been fit with both linear and nonlinear solutions with equations:

$$
V_{p}=3.56 \rho-4.26 \mathrm{~km} / \mathrm{sec}
$$

and

$$
V_{p}=0.08 \rho^{3} .63+2.33 \mathrm{~km} / \mathrm{sec}
$$

The coarse-grained, high-velocity samples recovered from Site 293 fall predictably above the basalt data distribution and have not been included in these solutions. The basalt from Site 294 is unusually rich in calcite which accounts for its anomalously high velocity with respect to either solution.

\section{DISCUSSION}

Examination of Table 1 suggests that at pressures appropriate to the sea floor $(0.4-0.6 \mathrm{~kb})$, velocities increase

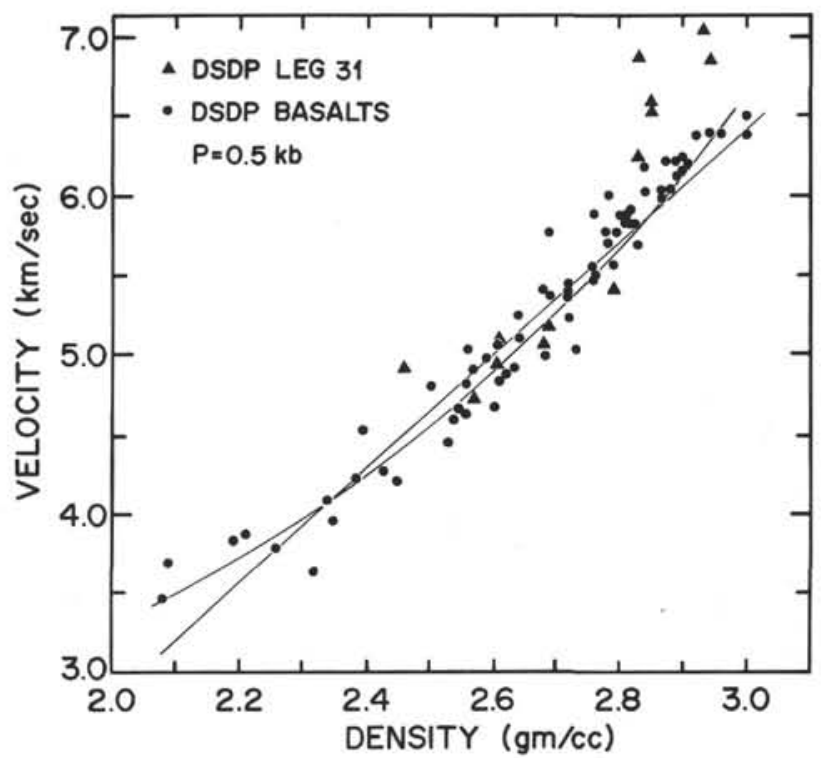

Figure 1. Compressional wave velocity versus bulk density for DSDP basalts and samples from Leg 31 at $0.5 \mathrm{~kb}$. Included are least squares, linear, and nonlinear solutions to the data.

with basement recovery depth at both Sites 292 (Figure 2 ) and 293. At Site 292, observed velocity gradients (Table 3 ) are clearly related to increasing density accompanying a decrease in both vesicularity and weathering with depth. At Site 293, velocity differences are associated with a change in lithology from metadiabase through hornblende metagabbro to anorthositic gabbro.

TABLE 2

Elastic Constants

\begin{tabular}{lccccccccc}
\hline $\begin{array}{c}\text { Sample } \\
\text { (Interval in cm) }\end{array}$ & $\begin{array}{c}\text { Pressure } \\
(\mathrm{kb})\end{array}$ & $\begin{array}{c}V / V \\
p\end{array}$ & $\sigma$ & $\begin{array}{c}\phi \\
(\mathrm{km} / \mathrm{sec})^{2}\end{array}$ & $\begin{array}{c}K \\
(\mathrm{mb})\end{array}$ & $\begin{array}{c}\beta \\
\left(\mathrm{mb}^{-1}\right)\end{array}$ & $\begin{array}{c}\mu \\
(\mathrm{mb})\end{array}$ & $\begin{array}{c}E \\
(\mathrm{mb})\end{array}$ & $\begin{array}{c}\lambda \\
(\mathrm{mb})\end{array}$ \\
\hline $31-292-41-2$, & 0.4 & 1.92 & 0.32 & 14.16 & 0.36 & 2.75 & 0.15 & 0.40 & 0.26 \\
$37-40$ & 1.0 & 1.94 & 0.32 & 15.38 & 0.40 & 2.53 & 0.16 & 0.43 & 0.29 \\
& 2.0 & 1.94 & 0.32 & 16.46 & 0.42 & 2.36 & 0.18 & 0.46 & 0.31 \\
$31-292-41-5$, & 4.0 & 1.96 & 0.32 & 18.14 & 0.47 & 2.13 & 0.19 & 0.49 & 0.35 \\
$40-43$ & 0.4 & 1.96 & 0.32 & 15.80 & 0.41 & 2.42 & 0.17 & 0.44 & 0.30 \\
& 1.0 & 1.93 & 0.32 & 16.24 & 0.43 & 2.35 & 0.18 & 0.47 & 0.31 \\
& 2.0 & 1.92 & 0.31 & 17.24 & 0.45 & 2.21 & 0.19 & 0.50 & 0.32 \\
$31-292-42-5$, & 4.0 & 1.93 & 0.32 & 18.53 & 0.49 & 2.05 & 0.21 & 0.54 & 0.35 \\
$29-32$ & 0.4 & 1.91 & 0.31 & 16.46 & 0.43 & 2.33 & 0.18 & 0.48 & 0.31 \\
& 1.0 & 1.91 & 0.31 & 17.00 & 0.44 & 2.25 & 0.19 & 0.51 & 0.32 \\
$31-292-43-4$, & 2.0 & 1.91 & 0.31 & 17.67 & 0.46 & 2.16 & 0.20 & 0.53 & 0.33 \\
$40-43$ & 6.0 & 1.91 & 0.31 & 18.54 & 0.49 & 2.05 & 0.21 & 0.55 & 0.35 \\
& 0.4 & 1.87 & 0.30 & 15.74 & 0.42 & 2.37 & 0.19 & 0.50 & 0.29 \\
$31-292-44-4$, & 1.0 & 1.88 & 0.30 & 16.62 & 0.45 & 2.24 & 0.20 & 0.52 & 0.31 \\
$48-51$ & 2.0 & 1.89 & 0.30 & 17.25 & 0.46 & 2.16 & 0.21 & 0.54 & 0.32 \\
& 4.0 & 1.89 & 0.30 & 17.83 & 0.48 & 2.08 & 0.22 & 0.56 & 0.34 \\
$31-294-7-1$, & 0.4 & 1.88 & 0.30 & 16.54 & 0.44 & 2.25 & 0.20 & 0.53 & 0.31 \\
$116-119$ & 1.0 & 1.88 & 0.30 & 17.30 & 0.47 & 2.15 & 0.21 & 0.55 & 0.33 \\
& 2.0 & 1.88 & 0.30 & 17.74 & 0.48 & 2.09 & 0.22 & 0.57 & 0.33 \\
& 4.0 & 1.88 & 0.30 & 18.44 & 0.50 & 2.00 & 0.23 & 0.59 & 0.35 \\
& 0.4 & 1.99 & 0.33 & 14.62 & 0.36 & 2.77 & 0.14 & 0.36 & 0.27 \\
& 1.0 & 1.95 & 0.32 & 14.82 & 0.37 & 2.73 & 0.15 & 0.39 & 0.27 \\
& 2.0 & 1.91 & 0.31 & 15.09 & 0.37 & 2.68 & 0.16 & 0.42 & 0.27 \\
& 4.0 & 1.89 & 0.31 & 15.86 & 0.39 & 2.53 & 0.17 & 0.46 & 0.28 \\
\hline
\end{tabular}




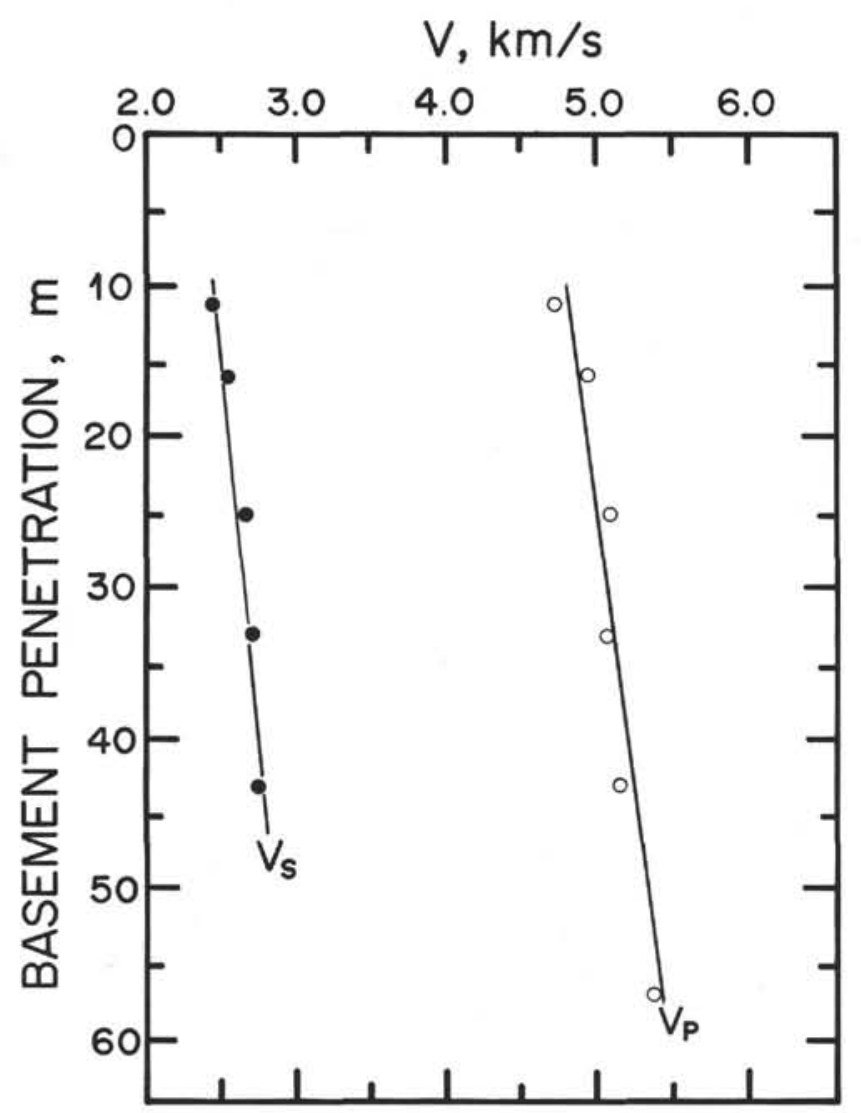

Figure 2. Measured velocity versus basement penetration at Site 292.

TABLE 3

Compressional and Shear Wave Velocity Gradients

\begin{tabular}{c|c|c}
\hline & $\frac{\partial V_{p} / \partial z}{(\mathrm{~km} / \mathrm{sec})}$ & $\frac{\partial V_{s} / \partial z}{m}$ \\
\hline $\begin{array}{c}(\mathrm{km} / \mathrm{sec}) \\
m\end{array}$ \\
\hline Site 292 & 0.012 & 0.009 \\
\hline
\end{tabular}

Straightforward comparisons of seismic refraction data for the Philippine Sea (Murauchi et al., 1968) with velocity data presented here are difficult because of both poor overlap of refraction lines with DSDP sites and the structural complexities seemingly inherent to marginal basins (Karig, 1971). Site 292, for instance, lies on the flank of the Benham Rise, whereas Sites 293 and 296 mark the extensions of the Central Basin Fault and the Palau-Kyushu Ridge, respectively. General seismic properties of the main basin of the Philippine Sea, however, are correlative with the seismic properties of crystalline rocks recovered on Leg 31 . The mean Layer 2 velocity reported for the abyssal plains of the Philippine Sea (Murauchi et al., 1968) is $4.86 \mathrm{~km} / \mathrm{sec}$ with a standard deviation of $0.18 \mathrm{~km} / \mathrm{sec}$, a range which clearly embraces most of the velocities at $0.4-0.6 \mathrm{~kb}$ of volcanic rocks recovered from Sites 292 and 294 (Table 1). This general agreement suggests that basalts similar to those measured in this study constitute a large portion of the crustal basement of the basins of the Philippine Sea. Layer 3 of the abyssal plains in this region has a mean $V_{p}$ of $6.76 \mathrm{~km} / \mathrm{sec}$ with a standard deviation of 0.14 $\mathrm{km} / \mathrm{sec}$. Velocities (at $1 \mathrm{~kb}$ ) determined for the plutonic rocks recovered from Site 293 (Table 1), the highest yet reported for DSDP samples, fall within the range of layer 3 velocities implying that these rocks may be important petrologic elements of Layer 3 in the Philippine Sea. It is suggested that tectonic activity of the Central Basin Fault may have introduced these rocks to the ocean floor from the deeper levels of the crust in this region. Alternatively, these rocks may have formed in situ as new ocean crust within a leaky transform fault by mechanisms outlined by van Andel et al. (1969). It is interesting to note that the samples examined are similar to those commonly observed in both dredge hauls in main basin fracture zones and in ophiolite complexes. Verification of these implications, however, depends on future determinations of the shear wave velocities of these rocks and the shear wave velocity structure in the neighborhood of the Central Basin Fault.

\section{ACKNOWLEDGMENTS}

We wish to thank R. McConaghy and M. Brown for technical assistance. This investigation was supported by the Office of Naval Research Contract N-00014-67-A-0014 and National Science Foundation Grant GA-36138.

\section{REFERENCES}

Birch, F., 1960. The velocity of compressional waves in rocks to 10 kilobars, I: J. Geophys. Res., v. 65, p. 1083.

Christensen, N.I., 1970. Compressional wave velocities in basalts from the Juan de Fuca Ridge: J. Geophys. Res., v. 75 , p. 2773.

Christensen, N.I. and Salisbury, M.H., 1972. Sea floor spreading, progressive alteration of Layer 2 basalts, and associated changes in seismic velocities: Earth Planet. Sci. Lett., v. 15, p. 367.

1973. Velocities, elastic moduli and weathering-age relations for Pacific Layer 2 basalts: Earth Planet. Sci. Lett., v. 19, p. 461.

Christensen, N.I., Fountain, D.M., Carlson, R.L., and Salisbury, M.H., 1974. Velocities and elastic moduli of volcanic and sedimentary rocks recovered on DSDP Leg 25: In Simpson, E.S.W., Schlich, R., et al., Initial Reports of the Deep Sea Drilling Project, Volume 25: Washington (U.S. Government Printing Office), p. 357.

Karig, D.E., 1971. Origin and development of marginal basins in the Western Pacific: J. Geophys. Res., v. 76, p. 2542.

Murauchi, S., Den, N., Asano, S., Hotta, H., Yoshii, T., Asanuma, T., Hagiwara, K., Ichikawa, K., Sato, T., Ludwig, W.J., Ewing, J.I., Edgar, N.T., and Houtz, R.E., 1968. Crustal structure of the Philippine Sea: J. Geophys. Res., v. 73, p. 3143.

Nur, A. and Simmons, G., 1969. The effect of saturation on velocity in low porosity rocks: Earth Planet. Sci. Lett., v. 7, p. 183.

van Andel, Tj.H., Phillips, J.D., and von Herzen, R.P., 1969. Rifting origin for the Vema Fracture in the North Atlantic: Earth Planet. Sci. Lett., v. 5, p. 296.

Wyllie, M.R.J., Gregory, A.R., and Gardner, G.G.F., 1958. An experimental investigation of factors affecting elastic wave velocities in porous media: Geophysics, v. 23, p. 459. 